\title{
Feline Spinal Muscular Atrophy
}

\author{
Commentary on the article by He et al. on page 324
}

\author{
SUSAN T. IANNACCONE
}

$S^{p}$ pinal muscular atrophy (SMA), OMIM \#253300), is a neurodegenerative, genetic disease of the anterior horn cell with a frequency of 8 per 100,000 live births $(1,2)$. It is associated with profound hypotonia and weakness with preservation of mental status. Childhood SMA has been classified into three types according to age of onset, severity of disease and motor milestones achieved (3). SMA type I presents before age 6 mo and carries a high rate of mortality during infancy. SMAI babies never are able to sit alone when placed and often suffer failure to thrive secondary to inability to suck or swallow. The prevalence rate is greatest for types II and III that are associated with later onset and lower mortality during mid and late childhood. Death almost always is secondary to severe restrictive lung disease that is progressive, although muscle weakness may be quite stable over decades (4). The disease is caused by loss of the SMN1 gene, the product of which is called the SMN protein. The severity of disease is inversely related to the number of copies of the diseasemodifying gene, SMN2, and also to tissue levels of SMN mRNA or protein $(5,6)$. Evidence suggests that the number of viable motor neurons (as determined electrophysiologically in vivo) is proportional to both clinical strength and to SMN mRNA levels $(7,8)$.

SMA was recently proclaimed a focus disease for the National Institutes of Neurologic Disease and Stroke; this means that funding has been and will be directed toward proposals sent in response to calls for research into the basic mechanism of this disease, for development of new drugs for its treatment and for clinical trials for patients with SMA. The reasons why SMA has become a "hot topic" include:

1. There now is a defined molecular lesion for $>90 \%$ of cases.

2. All patients have at least one modifier gene, since complete loss of SMN genes is an embryonic lethal.

3. Levels of SMN protein in cells (as determined by the number of copies of modifier gene present) define disease severity.

4. There are at least 2 transgenic animal models that have been used successfully in preclinical trials of compounds.

5. Several active compounds are known, including several histone deacetylase inhibitors (HDACI), to affect SMN protein levels and one may have actually modified the disease in a mouse model.

6. Clinical trials methodology is in place to carry out Phase II and Phase III studies.

In this issue, He et al. (9) report the clinical and histopathologic findings in a new, spontaneous model of SMA type III in purebred

Disease and Neurorehabilitation, TX Scottish Rite Hospital for Children, Professor of Neurology, UT Southwestern Medical Center, 2222 Welborn Street, Dallas TX 75219; e-mail: susan.iannaccone@utsouthwestern.edu
Maine coon cats, a long-haired domestic strain. Their findings are well documented and thoroughly investigated to show that the animal does indeed fit criteria for the diagnosis of SMA. Thirteen kittens from 4 pairings were affected, consistent with autosomal recessive inheritance. The initial symptoms beginning at 3-4 mo of age included weakness of hindlimbs causing an abnormal gait and tremor of hindlimbs. Mental status was preserved but animals showed muscle atrophy within one or 2 mo of onset. Weakness appeared to progress and involve respiration for as much as $8 \mathrm{mo}$ after which the cats stabilized.

This course of disease is very similar to that seen in children with SMAIII who may achieve motor milestones at normal ages, but develop gait abnormality with the onset of weakness (10). On the other hand, patients with SMAIII almost never develop restrictive lung disease, a typical complication of types I and II. Tremor is very common in human SMA but it is usually observed in the hands. It is typical for all patients with SMA to have an initial course during which weakness progresses followed by stabilization without recovery of strength.

Affected cats had elevation of serum creatine kinase and electrodiagnostic findings very similar to those seen in SMAIII, also known as Kugelberg-Welander disease (11). Likewise, muscle biopsy showed neurogenic atrophy, while examination of the central and peripheral nervous system showed that the primary abnormality was loss of anterior horn cells. The absence of upper motor neuron involvement ruled out the diagnosis of amyotrophic lateral sclerosis (ALS). Careful molecular investigation ruled out the possibility of mutations in feline SMN causing the disease and confirmed that the cat has only one SMN gene. The IGHMBP2 gene, mutations in which cause a severe, infantile form of SMA in human (SMARD1) (12) was also eliminated as the disease gene and linkage studies are underway.

The evidence is excellent to support the conclusion that the authors have found a new form of feline SMA. The importance of this animal model has yet to be determined. With two transgenic mice available for preclinical testing $(13,14)$, it would seem that the cat, a larger, more expensive animal to maintain, would not be useful for drug trials. However, therapies that may be challenged by the blood brain barrier (BBB), such as certain forms of antisense oligonucleotides (15) or possibly adenovirus mediated gene delivery (16), might be better tested in large animals like the cat. Transplanted embryonic germ cell derived cells ("embryoid body derived cells") have restored function to rats paralyzed after virus-induced motor neuronopathy, but require intrathecal injection and should be tried in higher vertebrates (17). Lentiviral vector gene delivery systems recently described in mouse models (18) travel from muscle to neuron using retrograde transport pathways, thereby avoiding the BBB. 
On the other hand, if linkage analysis results in the finding of another disease gene for SMA, then this cat may be extremely important. A new SMA gene could provide new insight into the mechanism of disease as well as motor neuron function or development. Alternatively, the gene for this feline disease could be related to genes known to cause ALS, such at SOD1 (19) or the recently described VAP-B locus (20), or even hereditary peripheral neuropathy (21).

As the National Institutes of Health has recognized, this is a watershed time for researchers studying SMA and for affected patients. The work of He et al. is a good example of unexpected but potentially very useful discovery.

\section{REFERENCES}

1. Emery AEH 1991 Population frequencies of inherited neuromuscular diseases - a world survey. Neuromuscul Disord 1:19-29

2. Merlini L, Stagni SB, Marri E, Granata C 1992 Epidemiology of neuromuscular disorders in the under-20 population in Bologna province, Italy. Neuromuscul Disord 2:197-200

3. Byers RK, Banker BQ 1961 Infantile Muscular Atrophy. Archives of Neurology 5:140-164

4. Birnkrant DJ, Pope JF, Martin JE, Repucci AH, Eiben RM 1998 Treatment of type I spinal muscular atrophy with noninvasive ventilation and gastrostomy feeding. Pediatr Neurol 18:407-410

5. Burghes AHM 1997 When is a deletion not a deletion? When it is converted. Am J Hum Genet 61:9-15

6. Mailman MD, Heinz JW, Papp A, Snyder PJ, Sedra MS, Wirth B, Burghes AH, Prio TW 2002 Molecular analysis of spinal muscular atrophy and modification of the phenotype by SMN2. Genet Med 4:20-26

7. Bromberg MB, Swoboda KJ 2002 Motor unit number estimation in infants and children with spinal muscular atrophy. Muscle \& Nerve 25:445-447

8. Swoboda KJ and Bromberg MB. Motor unit number estimation, SMN2 copy number and functional status in spinal muscular atrophy. Sixth Annual International Spinal Muscular Atrophy Research Group Meeting 6, 19. 2002. [Abstract]
9. He Q, Lowrie C, Shelton GD, Castellani RJ, Menotti-Raymond M, Murphy W, O'Brien SJ, Swanson WF, Fyfe JC Inherited Motor Neuron Disease in Domestic Cats: a Model of Spinal Muscular Atrophy. Pediatr Res 57:324-330

10. Hausmanowa-Petrusewicz I, Fidzianska A, Niebrój-Dobosz I, Strugalska MH 1980 Is Kugelberg-Welander spinal muscular atrophy a fetal defect? Muscle Nerve 3:389-402

11. Zerres K, Grimm t 1983 Genetic counseling in families with spinal muscular atrophy type Kugelberg-Welander. Hum Genet 65:74-75

12. Grohmann K, Varon R, Stolz P, Schuelke M, Janetzki C, Bertini E, Bushby K, Muntoni F, Ouvrier R, Van Maldergem L, Goemans NM, Lochmuller H, Eichholz S, Adams C, Bosch F, Grattan-Smith P, Navarro C, Neitzel H, Polster T, Topaloglu H, Steglich C, Guenther UP, Zerres K, Rudnik-Schoneborn S, Hubner C 2003 Infantile spinal muscular atrophy with respiratory distress type 1 (SMARD1). Ann Neurol 54:719-724

13. Ferri A, Melki J, Kato AC 2004 Progressive and selective degeneration of motoneurons in a mouse model of SMA. Neuroreport 15:275-280

14. Monani UR, Coovert DD, Burghes AHM 2000 Animal models of spinal muscular atrophy. Hum Mol Genet 9:2451-2457

15. Skordis LA, Dunckley MG, Yue B, Eperon IC, Muntoni F 2003 Bifunctional antisense oligonucleotides provide a trans-acting splicing enhancer that stimulates SMN2 gene expression in patient fibroblasts. Proc Natl Acad Sci USA 100:41144119

16. DiDonato CJ, Parks RJ, Kothary R 2003 Development of a gene therapy strategy for the restoration of survival motor neuron protein expression: implications for spinal muscular atrophy therapy. Hum Gene Ther 14:179-188

17. Kerr DA, Llado J, Shamblott MJ, Maragakis NJ, Irani DN, Crawford TO, Krishnan C, Dike S, Gearhart JD, Rothstein JD 2003 Human embryonic germ cell derivatives facilitate motor recovery of rats with diffuse motor neuron injury. J Neurosci 23:5131-5140

18. Azzouz M, Mazarakis N 2004 Non-primate EIAV-based lentiviral vectors as gene delivery system for motor neuron diseases. Curr Gene Ther 4:277-286

19. Feeney SJ, McKelvie PA, Austin L, Jean-Francois MJB, Kapsa R, Tombs SM, Byrne E 2002 Presymptomatic motor neuron loss and reactive astrocytosis in the SOD1 mouse model of amyotrophic lateral sclerosis. Muscle Nerve 24:1510-1519

20. Nishimura AL, Mitne-Neto M, Silva HCA, Richieri-Costa A, Oliveira JRM, Cascio D, Yamamoto LU, Vainzof M, Skehel P, Zatz M 2004 A novel locus for a late onset amyotrophic lateral sclerosis/motor neuron disease variant at 20q13. Neuromuscul Disord 14:563-564

21. Shy ME 2004 Charcot-Marie-Tooth disease: an update. Curr Opin Neurol 17:579-585 